\title{
PENGARUH KEKUASAAN POLITIK TERHADAP PEMBENTUKAN HUKUM DI INDONESIA
}

\author{
Oleh \\ Nuraini \\ Dosen Fakultas Hukum Universitas Batanghari \\ email : gadis.nuraini@gmail.com
}

\begin{abstract}
The state of Indonesia embraces the sovereighty of the people or democracy. The people are the owners of the highest power in the state. The real power comes from the people, by people, and for the people. Even idealized power is held together with the people. Indonesia itself is also a country that adheres to the law. From the opinion of the exparts we can see that the state that follows the rule of law is always related to power. Where power is always limited by the laws that bind it. In other words the sphere of power is limited by the rules that are bound by the rules that have been composed and written and made by the agency that is authoorized to make it.The type of research used is normative juridical research. This study uses " conceptual approach, legislation approach, and historical approach, in discussing the problems that exist in this research method is a way to perform analysis of data.Political power is the ability to use the source of influence to influence the process of making and executing political decisions so as to benefit itself, the group or society in general. Power is a gekala that always exist in the political process, in Indonesia law is a product of power (politics) so that the character of each legal product will be determined or colored by consideration of force political configuration that gave birthday.
\end{abstract}

Key word : Power, Political, Law

\section{A. PENDAHULUAN}

Suatu Negara yang menganut azas kedaulatan rakyat, disebut juga sebagai Negara demokrasi.(M.Kusnardi dan Hermaily Ibrahim, 1983: 130). Negara Indonesia juga menganut paham kedaulatan rakyat atau demokrasi. Rakyat adalah pemilik kekuasaan tertinggi dalam negara. Kekuasaan yang sesungguhnya adalah berasal dari rakyat, oleh rakyat, dan untuk rakyat. Kekuasaan bahkan diidealkan diselenggarakan bersama-sama dengan rakyat. Pemisahan kekuasaan (separation of power) ke dalam tiga lembaga yaitu legislatif, eksekuif, dan yudikatif yang sebenarnya adalah pelaksana kekuasaan yang mengabdi kepada rakyat sebagai pemilik kedaulatan negara yang sesungguhnya. Orangorang yang duduk disana adalah sebagai pelayan dan pengabdi yang bekerja demi kemakmuran dan kesejahteraan rakyat.

Negara Indonesia sendiri juga merupakan negara yang menganut hukum. Ini tertuang dalam Undang-undang Dasar Negara Republik Indonesia Tahun 1954 (selanjutnya disebut UUD 1945) pasal 1 ayat (3) yang berbunyi "Negara Indonesia adalah Negara hukum". 
Indonesia menganut sistem hukum. Tetapi tidak ditekankan apakah civil law ataupun common law. Tetapi didalam hal yang bersifat umum hukum tertulis merupakan primadona sebagai sumber hukum utama. Hal ini ditandai dengan munculnya suatu gerakan kodifikasi oleh aliran legisme. Aliran legisme dalam ilmu hukum dan peradilan tidak mengakui hukum diluar undang-undang. Aliran ini berpendapat bahwa hukum identik dengan undang-undang, sedangkan kebiasaan dan ilmu pengetahuan hukum, diakui sebagaihukum apabila undang-undang menunjuknya. Sistem hukum negara kita sangat mengedepankan pencapaian keadilan formal. Sistem ini cenderung menindas pihak yang lemah, miskin dan termarginal baik secara ekonomi, sosial, maupun politik.

Untuk memahami apa itu Negara hukum dalam artian yang sesungguhnya terlebih dahulu harus memahami pengartian dari negara hukum itu sendiri. Berikut adalah pendapat para ahli yang dikutip oleh Bahder Johan Nasution :

- Wiryono Projodikoro : Memberi pengertian Negara hukum sebagai Negara dimana para penguasa atau pemerintah sebagai penyelenggara Negara dalam melaksanakan tugas kenegaraan terkait pada peraturan peraturan hukum yang berlaku.

- Muhammad Yamin : Mendefinisikan Negara hukum sebgai suatu Negara yang menjalankan pemerintahan yang tidak menurut kemauan orang-orang yang memegang kekuasaaan, melainkan menurut aturan tertulis yang dibuat oleh badanbadan perwakilan rakyat yang dibentuk secara sah, sesuai dengan asas "the laws not menshall govern".

- Joeniarto : Negara hukum sebagai negara dimana tindakan penguasanya harus dibatasi oleh hukum yang berlaku.

- Sudargo Gautama : Paham negara hukum berasal dari ajaran kedaulatan hukum, ia member pengertian tentang negara hukum sebagai negara dimana alat-alat negaranya tunduk pada aturan hukum.

- Soediman Kartohadiprojo : Negara hukum sebagai negara dimana nasib dan kemerdekaan orang-orang didalamnya dijamin sebaik-baiknya oleh hukum (Bahder Johan Nasution, 2017: 1 ). 
Dari banyaknya pengertian ahli tersebut selalu dapat kita temui bahwa negara yang menganut negara hukum selalu berkaitan dengan kekuasaan. Dimana kekuasaan yang selalu dibatasi oleh hukum yang mengikatnya.

Dengan kata lain ruang gerak kekuasaan itu terbatas oleh peraturan-peraturan yang mengikatnya oleh peraturan yang telah tersusun dan tertulis serta dibuat oleh lembaga yang berwenang membuatnya.

Dalam Negara hukum, Tindakan penguasa dan Rakyat harus berdasarkan hukum (Abu Daud Busroh, 2010: 53.) Menurut Abu Daud Busroh negara hukum juga terbagi atas beberapa tipe yaitu Tipe Negara Hukum Liberal, Tipe Negara hukum liberal ini menghendaki agar supaya Negara berststus pasif artinya bahwa warga nega harus tuntuk pada peraturan-peraturan Negara.Penguasa dalam bertindak sesuai dengan hukm.Disisni kaum liberal menghendaki agar anata penguasa dan yang dikuasai ada suatu persetujuan dalam bentuk Hukum, serta persetujuan yang menguasai penguasa, Tipe Negara Hukum Formilyaitu negara hukum yang mendapat penegsahan dari rakyat, segala tindakan penguasa memerlukan bentuk hukum tertentu, harus berdasrkan undang-undang, Negara Hukum Formil ini disebut pula dengan Negara Demokratis yang berlandaskan Negara Hukum.

Dalam hal ini menurut STAHL seorang sarjana Denmark maka Negara Hukum Formil itu harus memenuhi 4 (empat) Unsur yaitu Bahwa Harus adanya jaminan terhadap hak-hak asasi, Adanya pemisahan Kekuasaan, Pemerintahan didasarkan pada undang-undang dan Harus ada peradilan administrasi.

Tipe Negara Hukum Materil adalah sebenarnya merupakan perkembangan lebih lanjut dari Negara Hukum Formil. Jadi apabila pada NegaraHukum Formil tindakan dari penguasa harus berdasarkan undang-undang atau harus berlaku asas legalitas, maka dalam Negara Hukum Materil tindakan dari penguasa dalam hal mendesak demi kepentingan warga negaranya dibenarkan bertindak menyimpang dari undang-undang atau berlaku asas Opportunitas (Abu Daud Busroh, 2010: 54). 
Selanjutnya lebih jauh Bahder Johan Nasution menyimpulkan tentang bagaimana ide dasar negara hukum Indonesia, yaitu tidak terlepas dari dari ide tentang "rechtstaat" yang syarat utamanya terdiri dari :

1. Asas legalitas, yaitu setiap tindakan pemerintah harus didasarkan atas dasar peraturan perundang-undangan;

2. Pembagian Kekuasaan, syarat ini mengandung makna bahwa kekuasaan negara tidak boleh hanya bertumpu pada satu tangan;

3. Hak-hak dasar, hak dasar merupakan sasaran perlindungan hukum bagi rakyat, dan sekaligus membatasi kekuasaan pembentuk undang-undang;

4. Tersedia saluran melalui pengadilan yang bebas untuk menguji

Dari uraian latarbelakang masalah di atas maka masalah yang di angkat dalam penelitian ini adalah Apakah yang disebut dengan kekuasaan politik itu, Bagaimana hubungan serta pengaruh kekuasaan politik terhadap pembentukan hukum di Indonesia dan Bagaimana keterkaitan teori hukum dalam pembentukan hukum di Indonesia.

\section{B. METODE PENELITIAN}

Tipe penelitian yang digunakan adalah penelitian yuridis normatif, yakni penelitian yang difokuskan untuk mengkaji penerapan kaidah-kaidah atau norma-norma dalam hukum positif.Penelitian ini menggunakan "pendekatan konseptual, pendekatan perundang-undangan, dan pendekatan sejarah (Bahder Johan Nasution,2008: 92).

Bahan-bahan hukum yang telah diperoleh, diinventarisasi dan diidentifikasi untuk digunakan sebagai bahan dalam menganalisis pokok permasalahan dalam penelitian ini. Identifikasi bahan hukum baik primer, sekunder, maupun tertier dilakukan secara kritis, logis, dan sistematis, dikumpulkan berdasarkan sistem kartu (card system), "yang memuat sumber yang tepat dari mana catatan itu diambil, informasi atau pendapat yang digunakan, pokok masalah serta kartu yang digunakan adalah kartu kutipan, kartu ulasan, kartu ikhtisar"(Bahder Johan Nasution,2008: 106) hal ini dilakukan untuk mempermudah proses pengolahan data hukum tersebut, dengan demikian bahan hukum akan disusun dan digolongkan menurut bentuk, jenis dan tingkatnya. 
Adapun bahan hukum yang digunakan dalam penelitian ini adalah Bahan hukum primer terdiri dari peraturan perundang-undangan yang berhubungan dengan masalah yang dibahas seperti UUD 1945, Undang-Undang, Peraturan Pemerintah, Peraturan Daerah, Yurisprudensi dan lain-lain, Bahan hukum sekunder yaitu bahan hukum yang dapat memberikan penjelasan mengenai bahan hukum primer, seperti rancangan undangundang, hasil-hasil penelitian, hasil karya dari kalangan hukum baik berbentuk buku, jurnal hukum, makalah dan lain-lain dan Bahan hukum tertier yakni bahan hukum yang dapat memberikan petunjuk maupun penjelasan terhadap bahan hukum primer dan sekunder. Dalam membahas permasalahan yang ada dalam penelitian ini metode yang digunakan metode deduktif yaitu cara untuk melakukan analisis atas data.

\section{KERANGKA TEORI/TINJAUAN PUSTAKA}

Kekuasaan adalah gejala yang selalu ada dalam proses politik, karena politik tanpa kekuasaan bagaikan agama tanpa moral karena begitu berkaitannya antara keduanya.

Menurut Miriam Budiardjo, ilmu politik adalah ilmu yang mempelajari tentang perpolitikan. Politik diartikan sebagai usaha-usaha untuk mencapai kehidupan yang baik (Miriam Budiardjo, 2009: 13). Politik sebagai suatu bagian kekuasaan diluar kekuasaan negara belaka berperan penting dalam produk hukum yang dihasilkan nantinya, produk hukum tersebutlah yang dinamakan produk politik.

Pengaruh politik dalam pembentukan hukum tampak jelas dalam pembentukan peraturan perundang-undangan. Tiap tahapan pembentukan peraturan perundangundangan tidak dapat terelakkan dari pengaruh politik, yang akhirnya berdampak pada substansi peraturan perundang-undangan yang dibentuk oleh pemerintah. Menurut Pasal 1 Angka 1 UU No.12 Tahun 2011, pembentukan peraturan perundang-undangan adalah Pembuatan peraturan perundang-undangan yang mencakup tahapan perencanaan, penyusunan, pembahasan, pengesahan atau penetapan dan pengundangan.

\section{PEMBAHASAN HASIL PENELITIAN DAN ANALISIS}

\section{Pengertian Kekuasaan Politik}


Kekuasaan dalam pembentukan hukum dalam hal ini Undang-udang di Indonesia berada pada kekuasaan legislatif dan eksekutif. Dimana DPR bersama Presiden berwenang untuk membuat undang-undang. Sedangkan bila dilihat dari tata cara pemilihan anggota DPR maupun Presiden itu melalui pemilihan umum. Pemilihan umum sendiri melewati proses perpolitikan yang berlangsung. Dimana para calon anggota DPR dan Presiden harus diusung dari partai politik yang telah terverifikasi oleh KPU.

Dari kenyataan bahwa DPR bersama Presiden di pilih melalui partai politik, kemudian setelah terpilih otomatis memiliki kekuasaan dalam membentuk hukum, maka bisa dikatakan bahwa kekuasaan disini bukan hanya kekuasaan biasa saja melainkan juga sebagai sebuah kekuasaan politik.

Negara Indonesia berdasarkan atas hukum, bukan berdasarkan atas kekuasaan belaka. Ini berarti bahwa antara pengertian hukum (rechtstaat) dan pengertian kekuasaan (machtstaat) dipertentangkan, kerana melihat negara semata mata mengandalkan kekuasaan belaka, sudah barang tentu tidak memperhartikan hukum. Kata-kata penguasa adalah peraturan perundang-undangan, oleh kerana itu perlu dibatasi oleh hukum. Tetapi keranahukum mutlak yang sifatnya transdental itu adalah syariah agama. Lalu negara Indonesia menempatkan Pancasila sebagai sumber dari segala sumber hukum, dimana agama merupakan sila pertama ( Inu Kencana Syafiie dan Azhari, 2012: 158).

Dalam pandangan sosiologis negara adalah bagian dari kelompok politik. Menurut Samidjo membagi politik kedalam dua jenis yaitu "politik teoritis" dan "politik praktis" yang dikutip oleh Sabian Utsman :

a. Politik Teoritis;mengenai keseluruhan dari asas-asas dan cirri-ciri yang khas dari negara tanpa membahas aktivitas dan tujuan-tujuan yang hendak dicapai oleh negara.

b. Politik Praktis ; mempelajari negara sebagai suatu lembaga yang bergerak dengan fungsi-fungsi dan tujuan-tujuan tertentu, yaitu negara sebagai lembaga yang dinamis (Sabian Utsman, 2009: 192-193).

\section{Pengaruh Kekuasaan Politik Terhadap Pembentukan Hukum Di Indonesia}

Untuk menjamin dilaksanakannya fungsi hukum dengan baik maka diperlukan suatu kekuasaan. Kekuasaan dalam hal penerapan kebijakan hukum seingkali dikaitkan dengan politik (policy $=$ kebijakan). Bila konsep tersebut dihubungkan dengan konsep 
politik, maka kekuasaan merupakan tujuan dari politik. Kekuasaan disini artinya kemampuan untuk mempengaruhi pihak lain agar pihak tersebut memenuhi keinginan yang berkuasa.Kekuasaan ini kemudian digunakan untuk mencapai esensi utama dalam hukum yaitu keadilan. Dalam pandangan aliran postivisme (hukum positif), kekuasaan digunakan untuk memonopoli tujuan dari hukumhukum dengan instrumen sanksi. Sanksi digunakan oleh penguasa kepada para pembangkang untuk menentukan hukum, serta adil dan ketidakadilan.

Dalam proses pembentukan peraturan hukum oleh institusi politik peranan kekuatan politik yang duduk dalam institusi politik itu adalah sangat menentukan. Institusi politik secara resmi diberikan otoritas untuk membentuk hukum hanyalah sebuah institusi yang vacum tanpa diisi oleh mereka diberikan kewenangan untuk itu. karena itu institusi politik hanya alat belaka dari kelompok pemegang kekuasaan politik. Kekuatankekuatan politik dapat dilihat dari dua sisi yakni sisi kekuasaan yang dimiliki oleh kekuatan politik formal (institusi politik) dalam hal ini yang tercermin dalam struktur kekuasaan lembaga negara, seperti Presiden, Dewan Perwakilan Rakyat dan lembagalembaga negara lainnya dan sisi kekuatan politik dari infrastruktur politik adalah seperti: partai politik, tokoh-tokoh masyarakat, organisasi kemasyarakatan, Lembaga Swadaya Masyarakat, organisasi profesi dan lain-lain. Dengan demikian dapatlah disimpulkan bahwa pembentukan produk hukum adalah lahir dari pengaruh kekuatan politik melalui proses politik dalam institusi negara yang diberikan otoritas untuk itu. Bahwa teori-teori hukum yang berpengaruh kuat terhadap konsep-konsep dan implementasi kehidupan hukum di Indonesia adalah teori hukum positivisme. Pengaruh teori ini dapat dilihat dari dominannya konsep kodifikasi hukum dalam berbagai jenis hukum yang berlaku di Indonesia bahkan telah merambat ke sistem hukum internasional dan tradisional.

Hukum merupakan produk politik sehingga karakter setiap produk hukum akan sangat ditentukan atau diwarnai oleh pertimbangan kekuatan atau konfigurasi politik yang melahirkannya. Hal ini berdasarkan kenyataan bahwa setiap produk hukum merupakan keputusan politik sehingga hukum dapat dilihat sebagai kristalisasi dari pemikiran politik yang saling berinteraksi dikalangan para politisi. Meskipun dari sudut "das sollen” ada pandangan bahwa politik harus tunduk pada ketentuan hukum, namun darisudut "das 
sein" bahwa hukumlah yang dalam kenyataannya ditentukan oleh konfigurasi politik yang melahirkannya.

Di Indonesia DPR bersama Presiden yang mempunyai kekuasaan dipilih melalui proses perpolitikan. Hal ini pula memicu hasil dari produk hukum yang dihasilkan berdasarkan keinginan politik. Menurut Soerjono Soekanto :

Ditinjau dari sudut ilmu politik, hukum merupakan suatu sarana dari elit yang memegang kekuasaan dan sedikit banyaknya dipergunakan sebagai alat untuk mempertahankan kekuasaan, atau untuk menambah serta mengembangkanya. Secara sosiologis, elit tersebut merupakan golongan kecil dalam masyarakat yang mempunyai kedudukan yang tinggi atau tertinggi dalam masyarakat dan yang biasanya berasal dari lapisan atas atau menegah atas. Baik buruknya suatu kekuasaan, tergantung bagaimana kekuasaan tersebut dipergunakan. Artinya, baik-buruknya kekuasaam senantiasa harus diukur dengan kegunaannya untuk mencapai suatu tujuan yang sudah ditentukan atau disadari oleh masyarakat tersebut lebih dahulu. Hal ini merupakan suatu unsure yang mutlak bagi kehidupan masyarakat yang tertib dan bahkan bagi setiap bentuk organisasi yang teratur. Akan tetapi, karena sifat dan hakikatnya, kekuasaan tersebut supaya dapat bermanfaat harus ditetapkan ruang lingkup, arah, dan batas-batasnya. Untuk itu diperlukan hukum yang ditetapkanoleh penguasa itu sendiri yang hendak dipegang dengan teguhb (Soerjono Soekanto, 2012: 15-16).

Jadi dapat dilihat bahwa pemegang kekuasaan pembuat hukum berasal dari stratifikasi social yang lebih tinggi dibandingkan dengan kebanyakan masyarakat yang ada. Dengan kata lain mereka adalah orang orang yang dipercaya oleh sekelompok orang untuk mewakilkan hasrat kehendak masyarakat banyak. Akan tetapi, kalau melihat dari iklim politik Indonesia. Saat ini negara kita sedang terjadi relasi Das sein, dimana politisasi dominan terhadap produk hukum. Sehingga produk yang dihasilkan tak lebih dari kristalisasi tawar-menawar antar elite politik. Ilmu hukum juga merupakan ilmu bantu dalam ilmu politik.

Pengaruh politik dalam pembentukan hukum tampak jelas dalam pembentukan peraturan perundang-undangan. Tiap tahapan pembentukan peraturan perundangundangan tidak dapat terelakkan dari pengaruh politik, yang akhirnya berdampak pada 
substansi peraturan perundang-undangan yang dibentuk oleh pemerintah. Menurut Pasal 1 Angka 1 UU No.12 Tahun 2011, pembentukan peraturan perundang-undangan adalah Pembuatan peraturan perundang-undangan yang mencakup tahapan perencanaan, penyusunan, pembahasan, pengesahan atau penetapan dan pengundangan.

Peraturan Perundang-undangan merupakan bagian dari hukum dan memiliki nilai yang urgen bagi perkembangan sistem hukum Indonesia kedepannya. Adapun yang dimaksud dengan peraturan perundang-undangan adalah peraturan tertulis yang memuat norma hukum yang mengikat secara umum dan dibentuk atau ditetapkan oleh lembaga negara atau pejabat yang berwenang melalui prosedur yang ditetapkan dalam peraturan perundang-undangan.

Berbagai jenis peraturan perundang-undangan di Indonesia yang terdapat dalam Pasal 7 UU No. 12 Tahun 2011, dalam praktiknya pembentukan peraturan perundangundangan tersebut belum mencerminkan secara optimal landasan, asas dan proses pembentukan peraturan perundang-undangan yang baik, sehingga produk peraturan perundang-undangan yang dihasilkan banyak memunculkan permasalahan kedepannya khususnya permasalahan penegakan hukum. Bahkan, tidak dapat dinafikan peraturan perundang-undangan yang telah disahkan dan diundangkan dimintakan pengujian kepada Mahkamah Konstitusi dan Mahkamah Agung.

\section{Teori Hukum Yang Mempengaruhi Pembentukan Hukum Indonesia}

Politik dan hukum sangat berhubungan karena ada intervensi politik terhadap hukum, politik kerapkali melakukan intervensi terhadap pembentukan dan pelaksanaan hukum. Hukum dalam arti peraturan merupakan kristalisasi dari kehendak-kehendak politik yang saling berinteraksi dan bersaingan.

Berbicara tentang politik dan hukum, jika dilihat apa yang dikatakan Roscoe Pound hukum itu berasal dari pemerintah selanjutnya dijalankan oleh masyarakat. Berbeda dengan Carl von Savigny yang mengatakan bahwa hukum itu berasal dari jiwa masyarakat (volksgeist). Maka dari itu kita akanmelihat dari dua sudut pandang yang terdapat pada teori Pounda dan Savigny dalam penerapannya di Indonesia.

Roscoe Pound adalah salah satu ahli hukum yang beraliran Sociological Jurisprudence yang lebih mengarahkan perhatiannya pada "Kenyataan Hukum" daripada 
kedudukan dan fungsi hukum dalam masyarakat. Aliran ini sebenarnya berkembang di Amerika, menurut aliran ini Hukum yang baik adalah hukum yang sesuai dengan hukum yang hidup didalam masyarakat. Berarti disini bahwa hukum itu mencerminkan nilai nilai yang hidup dimasyarakat (Lili Rasjidi dan Ira Thania Rasjidi, 2007: 66)

Sebuah pertanyaan pastinya mengemuka, lantas "sociological jurisprudence" sesungguhnya terletak di sudut pandang mana, apakah sebagai pengamat ataukah sebagai partisipan? Jawabanya adalah sebuah kemewahan dan keistimewaan sociological jurisprudence dengan menggabungkan kedua-duanya sudut pandang tersebut. Sehingga dalam bahasa sederhana sociological jurisprudence pada intinya mempelajari hukum dan sosial secara timbal balik. Di sinilah letak perbedaan sosiologi hukum (legal sociology) dan sociological jurisprudence. Kalau sosiologi hukum hanya memandang hukum dari satu arah, sementara sociological jurisprudence justru anatara hukum dan sosial samasama dapat saling mempengaruhi (resiprositas) (Lili Rasjidi dan Ira Thania Rasjidi, 2007: 67).

Law as a tool of Social Engineering (Zainuddin Ali, 2016: 3) yang dikemukakan Pound terkenal dengan teorinya bahwa hukum adalah alat untuk memperbarui (merekayasa) masyarakat.

Roscoe Pound mengungkapkan bahwa hukum itu bertujuan untuk menata perubahan masyarakat. Inilah yang disebut dengan "Law as a tool of social engineering". Dalam teori ini menurut Pound hukum itu menata kepentingan-kepentingan yang ada dalam masyarakat. Kepentingan-kepentingan itu harus ditata sedemikian rupa agar tercapai keseimbangan yang proporsional. Manfaatnya adalah terbangunnya suatu struktur masyarakat sedemikian rupa hingga secara maksimum mencapai kepuasan akan kebutuhan dengan seminimum mungkin menghindari benturan dan pemborosan (Bernard L Tanya et.al., 2013: 140)

Von Savigny menyatakan bahwa terdapat hubungan organic antara hukum dengan watak atau karakter suatu bangsa. Hukum hanyalah cerminan dari volkgeist (Bernard L Tanya et.al., 2013: 94) Von Savigny yang menyatakan bahwa hukum itu tidak dibuat melainkan tumbuh dan berkembang bersama-sama dengan masyarakat. Konsep ini dipengaruhi oleh agama (supranatural), Dengan pernyataan Savigny yang demikian itu 
maka hukum di satu negara tidak dapat diterapkan/ dipakai oleh negara lain karena masyarakatnya berbeda-beda begitu juga dengan kebudayaan yang ada di suatu daerah sudah pasti berbeda pula, dalam hal tempat dan waktu juga berbeda, seperti halnya yang berlaku di Indonesia (pengaruh mazhab sejarah) dengan berlakunya hukum adat.

Pokok-pokok ajaran mazhab historis yang diuraikan Savigny dan beberapa pengikutnya dapat disimpulkan sebagai berikut :(Yuriandi, Agung, "Perbandingan Teori Hukum Menurut Roscoe Pound dan Friedrich Karl Von Savigny dipandang dari perspektif Politik Hukum", (http://agungyuriandi.blogspot.co.id/2008/12/perbandingan-teorihukum-menurut-roscoe.html, diunduh pada Jum'at, 9 Februari 2018, jam 08.00 wib):

a. Hukum yang ditemukan tidak dibuat. Pertumbuhan hukum pada dasarnya adalah proses yang tidak disadari dan organis; oleh karena itu perundang-undangan adalah kurang penting dibandingkan dengan adat kebiasaan

b. Karena hukum berkembang dari hubungan-hubungan hukum yang mudah dipahami dalam masyarakat primitif ke hukum yang lebih kompleks dalam peradaban modern kesadaran umum tidak dapat lebih lama lagi menonjolkan dirinya secara langsung, tetapi disajikan oleh para ahli hukum yang merumuskan prinsip-prinsip hukum secara teknis. Tetapi ahli hukum tetap merupakan suatu organ dari kesadaran umum terikat pada tugas untuk memberi bentuk pada apa yang ia temukan sebagai bahan mentah (kesadaran umum tampaknya oleh Scholten disebut sebagai kesadaran hukum). Perundang-undangan menyusul pada tingkat akhir; oleh karena ahli hukum sebagai pembuat undang-undang relatif lebih penting daripada pembuat undangundang; dan

c. Undang-undang tidak dapat berlaku atau diterapkan secara universal. Setiap masyarakat mengembangkan kebiasaannya sendiri karena mempunyai bahasa adatistiadat dan konstitusi yang khas. Savigny menekankan bahwa bahasa dan hukum adalah sejajar juga tidak dapat diterapkan pada masyarakat lain dan daerah-daerah lain.Volkgeist dapat dilihat dalam hukumnya oleh karena itu sangat penting untuk mengikuti evolusi volkgeist melalui penelitian sepanjang sejarah.

Jadi, hukum itu berasal dari bawah ke atas. Dalam konteks bawah ini dapat dilihat bahwa hukum berasal dari masyarakat yang diwakilkan oleh Dewan Perwakilan Rakyat 
(DPR) sebagai wakil rakyat di dalam pemerintahan. Apa yang diinginkan oleh masyarakat akan diaspirasikan oleh DPR yang selanjutnya dibuat undang-undangnya dengan atau tidak persetujuan dari Presiden, karena DPR mempunyai hak inisiatif dalam pembuatan undangundang yang dapat disebut dari bawah-atas.

\section{E. PENUTUP}

Dari uraian diatas maka penulis mengambil beberapa kesimpulan yaitu:

1. Kekuasaan politik adalah kemampuan menggunakan sumber dari pengaruh untuk mempengaruhi proses pembuatan dan pelaksanaan keputusan politik sehingga menguntungkan dirinya, kelompoknya atau masyarakat secara umum. Kekuasaan adalah gejala yang selalu ada dalam proses politik, karena politik tanpa kekuasaan bagaikan agama tanpa moral karena begitu berkaitannya antara keduany.

2. Dari kenyataan di Indonesia bahwa DPR bersama Presiden di pilih melalui partai politik, kemudian setelah terpilih otomatis memiliki kekuasaan dalam membentuk hukum, maka bisa dikatakan bahwa kekuasaan disini bukan hanya kekuasaan biasa saja melainkan juga sebagai sebuah kekuasaan politik.

3. Bahwa di Indonesia Hukum merupakan produk kekuasaan (politik) sehingga karakter setiap produk hukum akan sangat ditentukan ataudiwarnai oleh pertimbangan kekuatan atau konfigurasi politik yang melahirkannya. Hal ini berdasarkan kenyataan bahwa setiap produk hukum merupakan keputusan politik sehingga hukum dapat dilihat sebagai kristalisasi dari pemikiran politik yang saling berinteraksi dikalangan para politisi.

\section{DAFTAR PUSTAKA}

\section{Buku}

Ali, Zainuddin. 2016. Sosiologi Hukum. Jakarta. Sinar Grafika.

Budiardjo, Miriam. 2010. Dasar-Dasar Ilmu Politik. Cet.II. Jakarta. PT. Gramedia Pustaka Utama.

Busroh, Abu Daud. 2007. Ilmu Negara, Cet. Ketujuh. Jakarta. PT. Bumi Aksara.

Kusnardi, Moh dan Hermaily Ibrahim. 1983. Pengantar Hukum Tata Negara Indonesia. Cet. V. Jakarta. Pusat Studi HTN Universitas Indonesia. 
Nasution, Bahder Johan. 2017. Negara Hukum Dan Hak Asasi Manusia, Cet.4. Bandung. CV.Mandar Maju.

Rahardjo, Satjipto. 2014. Ilmu Hukum, Cet 8. Bandung. PT.Citra Aditya Bakti.

Rasjidi, Lili dan Ira Thania Rasjidi. 2007. Dasar-dasar Filsafat dan Teori Hukum,cet 7. Bandung. PT.Citra Aditya Bakti.

Soekanto, Soerjono. 2012. Pokok-pokok Sosiologi Hukum, Cet.5. Jakarta. Rajawali Pers.

Syafiie, Inu Kencana dan Azhari. 2012. Sistem Politik Indonesia. Cet. VII. Bandung. Refika Aditama.

Tanya, Bernard L, et.al. 2013. Teori Hukum, strategi tertib manusia lintas ruang dan generasi. Yogyakarta. Genta Publishing.

Utsman, Sabian. 2009. Dasar-dasar Sosiologi Hukum. Yogyakarta. Pustaka Pelajar.

\section{Peraturan Perundang-Undangan}

Republik Indonesia, Undang-Undang Dasar Negara Republik Indonesia Tahun 1945.

, Undang-Undang Tentang Pembentukan Peraturan Perundang-undangan, Undang-Undang Nomor 12 Tahun 2011, Lembaran Negara No 82 Tahun 2011, Tambahan Lembaran Negara No.5234. 